\title{
OPTIMALISASI KEORGANISASIAN REMAS NURUR RAHMAN KOLPAJUNG DAN REMAS NURUL IMAN LAWANGAN DAYA
}

\author{
Kusyairi ${ }^{1}$, M. Khoiri ${ }^{1}$, Sukma Umbara TS ${ }^{1}$ \\ ${ }^{1}$ Universitas Madura Pamekasan \\ Email: kusyairi@unira.ac.id
}

\begin{abstract}
Abstrak
Sasaran kegiatan pengabdian kepada masyarakat ini adalah para pengurus dan anggota Remaja Masjid (Remas) di kedua mitra (Remas Nurur Rahman dan Remas Nurul Iman). Hasil kegiatan ini adalah berupa artikel yang dipublikasikan, adanya peningkatan pemahaman, pengetahuan, dan kreativitas bagi pengurus dan anggota remaja masjid, serta tersusunnya program kerja dan pelaksanaannya. Adapun metode pengabdian ini menggunakan metode observasi dan dilaksanakan dengan ceramah, diskusi dan demonstrasi/praktik langsung (baik penyusunan maupun pelaksanaannya di lapangan). Peserta pendidikan dan pelatihan dikelompokkan berdasarkan wilayah masing-masing. Masing-masing peserta kelompok akan diberikan panduan pelaksanaan kegiatan. Yakni, tentang pengelolaan organisasi mulai perencanaan organisasi, penyusunan program sampai evaluasi dan tindak lanjut program kegiatan. Adapun evaluasi pengabdian ini dilakukan di awal dan di akhir kegiatan sehingga diperoleh kesimpulan apakah pelaksanaan kegiatan ini memberikan nilai tambah terhadap peserta yang bersangkutan. Adapun kriteria keberhasilan kegiatan ini dapat ditinjau dari kehadiran peserta, penguasaan materi, penyusunan program kerja serta evaluasi program kerja remaja masjid. Hasil kegiatan ini adalah pelaksanaan training and development untuk memberikan pemahaman tentang organisasi dan kepemimpinan sangat membantu masyarakat dalam mengenali potensi sumber daya yang dimiliki daerahnya. Selan itu pelaksanaan program kerja remaja masjid yang berupa kreativitas menyusun dan melaksanaan program kerja ini mempunyai nilai lebih untuk dikembangkan.
\end{abstract}

Kata kunci: Organisasi, Remaja Masjid, Program Kerja

\section{PENDAHULUAN}

Masjid merupakan sarana beribadah umat muslim. Keberadaannya sangat mudah kita temui, mulai dari tingkat desa, kecamatan, kabupaten/ kota, bahkan tingkat provinsi dan nasional.
Pentingnya bangunan masjid ini, seakan menjadi prestise suatu daerah. Semakin bagus bangunan masjid di suatu wilayah, menandakan wilayah itu masyarakatnya semakin Islami. Masjidmasjid yang berdiri di suatu wilayah merupakan masjid pesantren, ulama 
setempat, dan masjid yang dibangun oleh swadaya masyarakat secara mandiri.

Kabupaten Pamekasan memiliki sekitar 500 bangunan masjid yang ada (data Kantor Kemenag Pamekasan Tahun 2016), serasa kurang maksimalnya manfaatnya bila belum memberikan pengaruh positif bagi masyarkat sekitar masjid. Sebagaimana diketahui bahwa fungsi masjid tidak hanya sebagai tempat ibadah saja, namun juga berfungsi sebagai pusat kegiatan lainnya, seperti kajian tentang keagamaan, diskusi kehidupan sosial dan dinamika masyarakat, pemberdayaan masyarakat, kegiatan perayaan hari besar Islam, ceramah, belajar baca tulis al-quran, dan lain sebagainya.

Salah satu cara untuk bisa mewujudkan itu, perlu memaksimalkan keberadaan Remaja Masjid atau biasa disebut Remas. Remaja masjid sebagai salah satu organisasi yang penting dalam pengelolaan masjid harus benarbenar diberdayakan untuk mewujudkan cita-cita menjadikan masjid sebagai pusat kehidupan masyarakat. Salah satunya, keberadaan masjid bisa memberdayakan ekonomi umat melalui mikro-kredit dan usaha mikro yang diselenggarakan dan dikelola oleh remas, sehingga bisa meningkatkan perekonomian masyarakat sekitar (Suryanto dan Saepulloh, 2016:18).

Ilmu manajemen perlu diterapkan dalam mengelola masjid di zaman modern seperti sekarang. Segala program pemberdayaan masjid perlu disusun sedemikian rupa, ditentukan siapa saja para penanggung jawab program-program tersebut, dilaksanakan secara serius dan istiqomah, serta dilakukan evaluasi terus-menerus secara berkala. Yang terpenting adalah, bagaimana merencanakan programprogram remas yang terukur. Jangan hanya asal menyusun perencanaan, namun tidak terlaksana dengan maksimal. Dari berbagai penelitian yang telah dilakukan, perencanaan merupakan hal yang penting dalam melakukan sebuah program. Perencanaan merupakan fondasi dalam melakukan manajemen kekinian. Pentingnya perencanaan bagi kegiatan remas supaya kegiatan yang akan dilaksanakan berjalan sesuai dengan rencana dimaksud (Zaini, 2016: 19).

Salah satu aktivitas masyarakat di lingkungan masjid yang tampak adalah adanya organisasi remaja masjid (Remas). Berdasarkan pengamatan tim pengabdi, dalam hal ini ada dua organaisasi Remas yang layak mendapatkan perhatian untuk dikembangkan sumber daya manusianya (pengurus dan anggota), yakni Remaja Masjid Nurur Rahman (mitra 1) dan Remaja masjid Nurul Iman (mitra 2).

Remas Nurur Rahman merupakan salah satu organisasi remaja yang ada di Kelurahan Kolpajung Kecamatan Pamekasan. Remas ini terdapat di RT 01 RW 04 dan memiliki anggota sebanyak 35 orang. Persebaran anggotanya meliputi para remaja setempat yang masih aktif menjadi siswa SMP/MTs, SMA/SMK/MA, bahkan aktif sebagai mahasiswa perguruan tinggi. Remas Nurur Rahman ini berada di dalam naungan Yayasan Nurur Rahman yang diasuh oleh Drs. K.H. Mudhar.

Adapun Remas Nurul Iman merupakan salah satu organisasi remaja yang ada di kelurahan Lawangan Daya 
DIFUSI

Volume 2, No.1 Januari 2019

Kecamatan Pademawu. Remas ini terdapat di RT 07 RW 03 dan memiliki anggota sebanyak 20 orang. Persebaran anggotanya meliputi para remaja setempat yang masih aktif menjadi siswa SMP/MTs, SMA/SMK/MA, bahkan aktif sebagai mahasiswa perguruan tinggi. Remas Nurul Iman ini berada di dalam naungan Yayasan Nurul Iman yang diasuh oleh K.H. Muhellis, SH.

Berdasarkan hasil wawancara awal yang dilakukan tim pengabdi di lembaga tersebut didapatkan bahwa sebagian besar pengurus dan anggota remaja masjid sering mengalami kesulitan untuk menyusun program kerja dikarenakan keterbatasan sumber daya pengurus dan anggota yang berpengalaman keorganisasiannya. Selain karena sumber daya manusianya, kondisi sarana dan prasarana juga kurang layak.

Oleh karena itu, tim pengabdi berinisiatif untuk melakukan berbagai upaya yang dapat meningkatkan kualitas sumber daya manusia remaja masjid di kedua organisasi tersebut. Mulai dengan pelatihan pembuatan perangkat keorganisasian, pelatihan penyusunan program kerja, serta pelatihan manajemen dan evaluasi program kerja remaja masjid. Hal ini mengingat kemampuan para pengurus dan anggota yang masih kurang, kreativitas pengurus dan anggota yang rendah serta keterbatasan organisasian dalam hal keuangan.

Sesuai dengan uraian di atas, maka tim pengabdi berkeinginan untuk memberikan beberapa pengetahuan teknologi dan manajemen keorganisasian yang diharapkan bermanfaat bagi organiasasi yang bersangkutan, sehingga pembelajaran dapat berlangsung dengan efektif dan efisien. Selain itu, dengan adanya peningkatan kreativitas para pengurus dan anggota di kedua remaja masjid tersebut secara tidak langsung akan dapat meningkatkan kualitas organisasi di kedua lembaga tersebut.

\section{METODE}

Pengabdian ini bersifat pemberdayaan secara 'riil' dalam memberdayakan remaja masjid di kedua mitra di Kelurahan Kolpajung dan Kelurahan Lawangan Daya. Kegiatan ini dilakukan melalui pendidikan dan pelatihan kepada masyarakat (remaja masjid Nurur Rahman Kolpajung dan Nurul Iman Lawangan Daya).

Kegiatan ini menggunakan metode observasi dan dilaksanakan dengan ceramah, demonstrasi dan diskusi. Kegiatan ini juga didukung oleh pihakpihak terlibat (stakeholders), yakni Takmir Masjid kedua mitra, remaja masjid kedua mitra, pemerintah desa serta kelompok mahasiswa dari Lembaga Dakwah Kampus Universitas Madura.

Alasan pemilihan objek penelitian para remaja masjid mitra (pengurus dan anggota) karena objek tersebut memiliki potensi dan kompetensi untuk dikembangkan dan diberdayakan demi kemajuan dan kemakmuran masjid. Para remaja masjid dipilih bertujuan untuk mengembangkan potensi masjid dan para pengurusnya perlu dibekali dengan kesadaran berorganisasi (merencanakan, melaksanakan dan mengevaluasi program kerja) dengan baik. Adanya pemahaman yang baik tentang organisasi dan pemberdayaannya bagi 
DIFUSI

Volume 2, No.1 Januari 2019

masyarakat diharapkan akan tertanam kreativitas dan peningkatan kompetensi para pengurusnya. Waktu dan tempat pelaksanaan kegiatan pengabdian Kepada Masyarakat adalah selama tiga bulan.

Bahan yang digunakan dalam kegiatan ini antara lain: panduan pendidikan dan pelatihan, LCD Proyektor, papan tulis, dan papan kayu program kerja remaja masjid. Aktivitas kegiatan ini diukur menggunakan instrumen dalam bentuk kuisioner yang divalidasi oleh para ahli dan data dianalisis secara deskriptif kualitatif.

Adapun tahapan program dilakukan adalah sebagai berikut:

\section{Pendataan Remaja Masjid Kelurahan Kolpajung dan Kelurahan Lawangan Daya;}

Pendataan ini diperlukan untuk mengetahui seberapa banyak remaja masjid yang mempunyai potensi untuk diberdayakan dan yang sangat membutuhkan pembinaan potensi dan kreativitas, sehingga remaja masjid bisa produktif menghasilkan program yang bernilai dan efektif, sehingga pengabdian ini tepat sasaran dan dapat dilaksanakan secara maksimal sehingga memberikan kontribusi yang nyata bagi masyarakat Kelurahan Kolpajung dan Kelurahan Lawangan Daya.

\section{Pelatihan tentang Cara Menyusun Program Kerja Organisasi;}

Pelatihan penyusunan program kerja untuk remaja masjid di kedua mitra (Masjid Nurur Rahman dan Masjid Nurul Iman).

\section{Persiapan untuk penerapan dari Pelatihan;}

Persiapan pengurus dan anggota remaja masjid untuk proses penerapan dari pelatihan; Mengumpulkan dalam bentuk kelompok yang sudah diberikan penjelasan tentang keorganisasian. Dikarenakan materi ini harus dipahami dengan sebaik-baiknya dalam waktu singkat maka mereka harus bkerja secara berkelompok; dan melakukan penerapan dari pelatihan.

\section{HASIL DAN PEMBAHASAN}

Kegiatan Program Kemitraan kepada Masyarakat yang berjudul Optimalisasi Keorganisasian Remaja Masjid Nurur Rahman Kolpajung dan Nurul Iman Lawangan Daya dilaksanakan menggunakan dua mitra dan di dua daerah yang berbeda. Tim Pengabdi sesuai dengan kepakaran memberikan kontribusi dalam kegiatan program Pogram Pengabdian Masyarakat.

Kegiatan pengabdian ini dilaksanakan sesuai dengan proses dan tahapan yang telah ditentukan yaitu mulai dari tahap persiapan sampai pelaksanaan.

Pengabdian Kepada Masyarakat dilaksanakan dalam bentuk kegiatan sebagai berikut:

\section{Tahap Persiapan}

Pada tahap ini, Tim Pengabdi dan para pengurus Remaja Masjid mendata berbagai masalah keorganisasian yang dimungkinkan untuk dioptimalisasikan dalam membuat program kerja dan pelaksanaannya. Kegiatan ini difokuskan pada hal-hal pokok dalam pengabdian, yakni pengelolaan 
DIFUSI

Volume 2, No.1 Januari 2019

organisasi remaja masjid dan peningkatan kreativitas para pengurus dalam menyusun program kerja.

\section{Tahap Pelaksanaan}

\section{a. Pemberian Materi tentang Pengelolaan Remaja Masjid}

Berkaitan dengan pemberian materi ini, para peserta diarahkan untuk mengamati perangkat pembelajaran yang berupa contoh pengelolaan masjid yang telah dilakukan, yang kemudian dilanjutkan dengan menentukan hal-hal penting yang akan dilakukan untuk mengelola organisasi remaja masjid.

Berdasarkan pilihan yang ditentukan, dalam kegiatan ini para pengurus dan anggota menentukan langkah-langkah dan berbagai manajemen/pengelolaan yang akan diterapkan dalam organisasi remaja masjid (baik itu berupa tata administrasi, tata keuangan, dan tata kerja anggota).

Tim Pengabdi menerapkan teknik dan metode yang telah dirancang. Sesuai dengan metode yang telah ditetapkan, dalam kegiatan ini yang diterapkan adalah: (1) Melakukan training and development, yakni untuk memberikan pemahaman tentang manjemen dan keorganisasian di lembaga mitra; (2) Melakukan creative thingking training tentang metode dan teknik menyusun program kerja bagi remaja masjid; (3) Melakukan pendampingan kepada pengurus dan anggota dalam pelaksanaan program kerja remaja masjid di lembaga mitra; dan (4) Melakukan pendampingan kepada pengurus dan anggota dalam pelaksanaan program kerja remaja masjid di lembaga mitra.

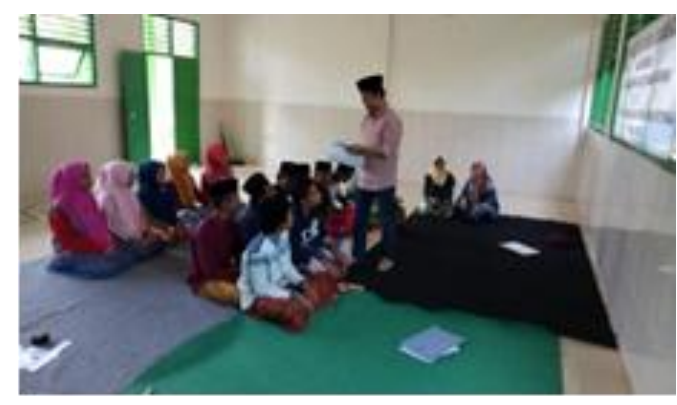

Gambar 1. Pelatihan Pengelolaan Organisasi

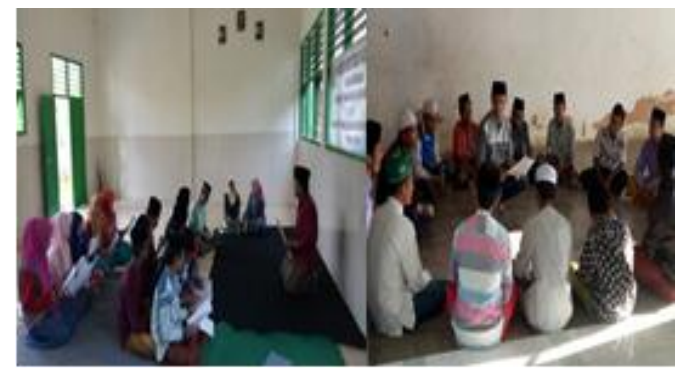

Gambar 2. Peserta Mengamati Materi Contoh-Contoh Pengelolaan Organisasi

\section{b. Proses Pelaksanaan Kegiatan Kreativitas}

Pelaksanaan penyusunan program kerja remaja masjid dilakukan dengan cara berkelompok, yakni masingmasing kelompok membuat program kerja dengan bidang yang dimilikinya.

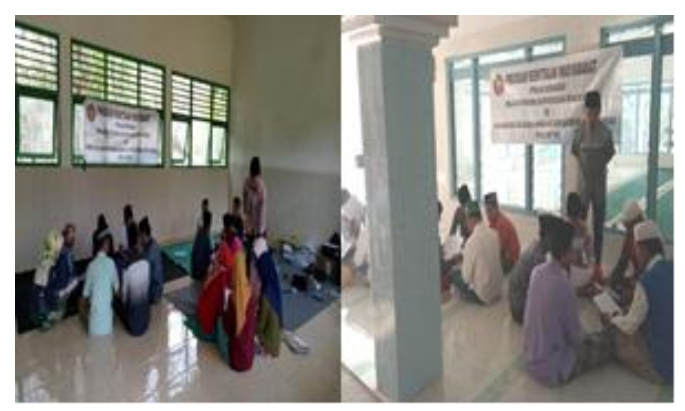

Gambar 3. Proses Penyusunan Program Kerja Remaja Masjid 


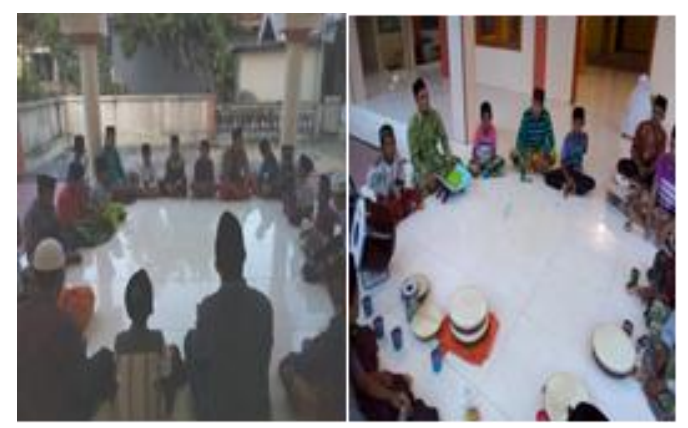

Gambar 4. Proses Pengarahan untuk Kreativitas Seni Hadrah Al Banjari

\section{c. Produk Hasil Kreativitas Remaja Masjid}

Adapun hasil dari kreativitas yang dihasilkan dari oleh para pengurus dan anggota remaja masjid mitra pengabdian adalah berupa perbaikan administrasi dan papan organisasi, serta kreativitas dalam seni hadrah $\mathrm{Al}$ Banjari.

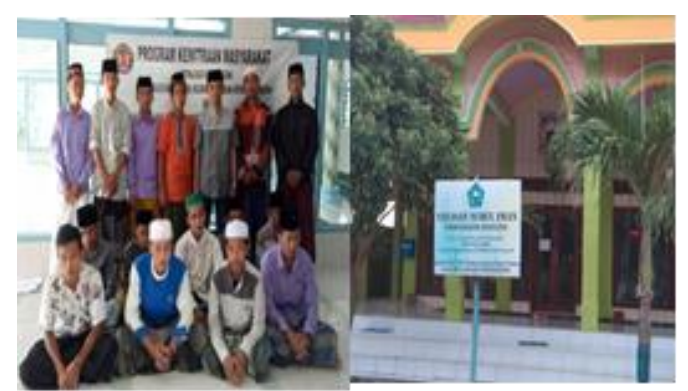

Gambar 5. Proses Pelatihan di Masjid Nurul Iman

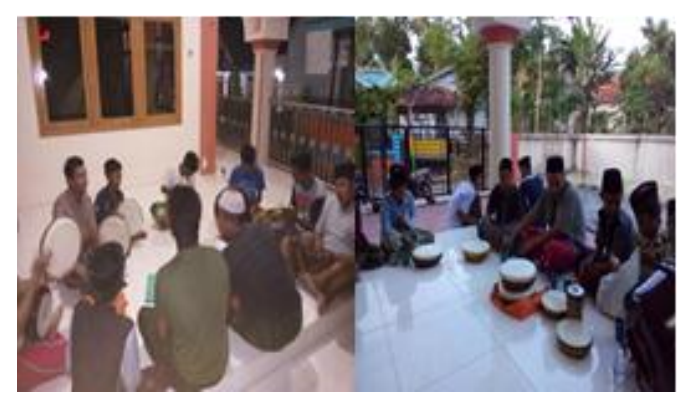

Gambar 6. Kreativitas Remaja Masjid Nurur Rahman

\section{d. Tindak Lanjut}

Setelah dilakukan pelatihan penyusunan program kerja terhadap kelompok remaja masjid, maka tindak lanjut dari kegiatan ini adalah:

1) Melakukan monitoring untuk memastikan pelaksanaan program kerja di kedua mitra.

2) Mengevaluasi proses penyusunan program kerja untuk mendapatkan hasil yang maksimal, baik desain, kualitas, maupun kuantitas.

3) Memberikan pendampingan dalam sosialisasi tentang pelaksanaan program kerja Remaja Masjid.

4) Mencarikan jaringan keluar untuk pengembangan kreativitas masyarakat (remaja masjid).

\section{e. Catatan Hasil dari \\ Pendampingan}

Berdasarkan hasil pendampingan, catatan yang dibuat antara lain:

1) Meningkatkan kompetensi dan kreativitas masyarakat, khususnya remaja masjid, dapat dilakukan dengan memanfatkan sumber daya manusia yang ada di sekitar tempat tinggal masyarakat.

2) Dibutuhkan kegiatan workshop dan pelatihan terhadap masyarakat secara terus menerus oleh pemerintah daerah (pemerintah desa) tentang pemberdayaan sumber daya manusia.

3) Pendampingan berkelanjutan sangat diperlukan untuk memupuk semangat dan kreativitas masyarakat (sekitar masjid). 
4) Pendampingan tidak cukup hanya pendampingan terkait dengan proses awal, tetapi yang lebih penting adalah pendampingan yang dapat membantu pengembangannya.

5) Mengelola organisasi remaja masjid dibutuhkan niat, keuletan, kreatifitas dan ketekunan setiap individu yang bersangkutan.

\section{KESIMPULAN}

Berdasarkan hasil kegiatan pengabdian kepada masyarakat dapat disimpulkan bahwa pelaksanaan training and development untuk memberikan pemahaman tentang organisasi dan kepemimpinan sangat membantu masyarakat dalam mengenali potensi sumber daya yang dimiliki daerahnya. Selain itu, penyusunan program kerja remaja masjid membutuhkan ketelatenan dan kemauan untuk dapat menghasilkan hasil yang baik. Sehingga dalam pelatihan dan pendampingan yang intensif mempengaruhi keberhasilan dan keberlanjutan pelaksanaan program kerja organisasi remaja masjid sebagai hasil kreatifitas untuk dapat menghasilkan program kerja yang menarik dan berkualitas. Selanjutnya, hasil pelaksanaan program kerja remaja masjid yang berupa kreativitas menyusun dan melaksanaan program kerja ini mempunyai nilai lebih untuk dikembangkan, oleh karena itu perlu pendampingan dan bimbingan yang terus menerus.

\section{REFERENSI}

[1] Adi, Rukminto, I. (2013). Intervensi Komunitas \& Pengembangan Masyarakat Sebagai Upaya Pemberdayaan Masyarakat Cet ke-2. Rajawali Pers. Jakarta.

[2] Arikunto, Suharsimi. (2002). Prosedur Penelitian Suatu Pendekatan Praktek. Cet ke-12 PT. Adi Maha Setya. Jakarta.

[3] Khoiri, M. dan Harsono. (2019). Pengolahan Sampah Anorganik Menjadi Media Pembelajaran Bagi Guru TK/RA. Jurnal Loyalitas. Vol I No. 2.

[4] Sugiyono. (2005). Memahami Penelitian Kualitatif. Cet ke-1 Alfa Beta. Bandung.

[5] Suryanto, Asep dan Asep Saepulloh. (2016). Optimalisasi Fungsi Dan Potensi Masjid: Model Pemberdayaan Ekonomi Masyarakat Berbasis Masjid Di Kota Tasikmalaya. Jurnal Iqtishoduna. Vol. 8 No. 2.

[6] Zaini, Ahmad. (2016). Manajemen Dakwah Ikatan Remaja Masjid Baiturrohman (Irmaba) Di Desa Pucakwangi Kecamatan Pucakwangi Kabupaten Pati. Tadbir Vol. 1 No. 2. 